\title{
Shelf-life Evaluation of Trichoderma sp. on Agricultural Waste Materials
}

\author{
Y. M. Suma*, T. Anil Kumar, S. Simon and A. A. Lal
}

Sam Higginbottom University of Agriculture, Technology and Sciences, Prayagraj- 211007, (UP) India

*Corresponding author

\section{Keywords}

Biological control, Pineapple peel formulation of Trichoderma sp.,Rhizoctoniasp., shelf-life, Talc based formulation.

Article Info

Accepted:

20 August 2019

Available Online:

10 September 2019

\section{A B S T R A C T}

An experiment was conducted both in in vitro and in situ during 2018-19 at Sam Higginbottom University of Agriculture, Technology And Sciences, Prayagraj. Under in vitro conditions, the shelf-life of fruit peel formulation of Trichoderma sp. and talc based formulation were evaluated up to 45 days at room temperature $\left(25-30^{\circ} \mathrm{C}\right)$. Among them, pineapple peel formulation of Trichoderma sp. $\left(2.6 \times 10^{8} \mathrm{cfu} / \mathrm{g}\right)$ showed longer shelf-life than that of the normal talc based formulation $\left(1.5 \times 10^{8} \mathrm{cfu} / \mathrm{g}\right)$. Under in situ conditions, Trichoderma formulations were tested against the root rot (Rhizoctonia sp.) disease of chilli, cucumber and radish. Application of pineapple peel formulation of Trichoderma sp. showed higher germination per centage inchilli (74.98\%), cucumber $(91.64 \%)$ and radish $(96.5 \%)$ when compared to talc based formulation. The present investigation concluded that application of pineapple peel formulation of Trichoderma sp. increased the grmination percentage, which was used as biofungicide for seed treatment, that efficiently fought against Rhizoctonia sp.

\section{Introduction}

Plant diseases especially soil-borne diseases are of major concern in cultivation of crops. Though chemical control is effective, it is not economic and is hazardous to the environment. There is a pressing need to control these diseases by using feasible alternate, which in recent times is satisfied by bio-control agents. Use of microbial antagonists in the biological control of plant disease is an alternative method for disease control that would also protect our environment from hazardous effects of the chemicals.

Trichoderma is one such free-living asexually reproducing filamentous fungi, which are known for their aggressive myco-parasitism, that makes them primary candidates as bio- 
control agents. They are one of the abundant fungi, virtually found in all types of soil and decaying wood and So far, Trichoderma spp. is among the most studied fungal BCAs and commercially marketed as biopesticides (Kamala and Devi, 2012). They are also used in industrial purpose for the production of cellulytic enzymes. The critical impediment in the use of biocontrol agents is lack of knowledge of methods for production and the delivery system. In order to overcome this limitation, the agricultural wastes that can give good spore yield, good shelf-life at ambient temperature and high percentage of viable spores of Trichoderma spp. have been evaluated. The present study was conducted to search suitable agricultural waste for the sporulation and growth of Trichoderma sp. and effect of substrates on the shelf life of the formulation. The effect of different formulations of Trichoderma sp. against Rhizoctonia sp. (root rot) of vegetable crops, was also evaluated.

\section{Materials and Methods}

\section{Agrowastes}

Agricultural waste materials viz. rice husk, wheat straw, rice chaffy grains, sawdust, these all in combination with cowdung and cowdung alone and waste peels of papaya, pineapple, pomegranate, potato, carrot and bottlegourd (Simon and Anamika, 2011) were evaluated for sporulation and growth of Trichoderma sp.; their shelf-life and germination percentage of vegetable crops on application of these formulations against Rhizoctonia sp. The above mentioned substrates and cut peels of fruits and vegetable wastes were filled in Petri plates. Three replicates for each substrate was maintained.

The culture of Trichoderma sp. was procured from the Department of Plant Pathology, Sam Higginbottom University of Agriculture,
Technology And Sciences (SHUATS), Prayagraj. Each Petri Plate was sprayed with two milliliters of spore suspension $\left(10^{5}\right.$ $\left.10^{6} \mathrm{cfu} / \mathrm{ml}\right)$, prepared by harvesting one week old culture of Trichoderma $s p$. in distilled water. The Petri plates were incubated at room temperature $\left(25-30^{\circ} \mathrm{C}\right)$ and they were observed for the sporulation and growth of Trichoderma after two days. The population of conidia per $\mathrm{ml}$ of suspension was determined by a haemocytometer using the following formula (Rajput et al., 2014) :

cfu per $\mathrm{ml}=$ No. of conidia in large square $\times$ dilution factor $\times 1.25 \times 10^{6}$

\section{Shelf-life evaluation of Trichoderma sp.}

The substrates for evaluating shelf-life were selected after observing the growth rate and sporulation pattern of Trichoderma sp. on it. After complete colonization of Trichoderma sp. on the substrates, the colonized agricultural wastes were shade dried and powdered.The powdered substrates were weighed and were mixed with the talc powder (carrier) in the ratio of $1: 2$, powdered substrate taken as one part and the talc powder taken as two parts (Sanjay, 2010). Then, the mixture of this powder was filled in polypropylene bags and was stored at room temperature. One week old culture of Trichoderma grown on PDA medium was mixed with talc powder and was used as check. Ten replicates for each treatment were maintained.

\section{Calculation of the colony forming units in stored formulations}

The estimation of colony forming units (cfu) of Trichoderma sp. in different formulations was done by suspending $1 \mathrm{~g}$ of the mixed product by serially diluting the powder in sterile distilled water and finally plating it on fresh Potato Dextrose Agar medium. The plates were incubated at $26-28^{\circ} \mathrm{C}$. The 
population counts of Trichoderma sp.in different formulation were repeated at every 15 days and continued up to 45 days. During storage period, the powdered formulations were stored in sealed polythene bags at room temperature $\left(25-30^{\circ} \mathrm{C}\right)$. The colony forming units were calculated by using formula (Schmidt and Caldwell, 1967):

cfu per gram $=$ cfu per plate $\mathrm{x}$ dilution factor

Weight of substrate $(\mathrm{g}) \mathrm{x}$ amount plated $(\mathrm{ml})$

\section{Calculation of per cent decrease in colony forming units}

Per cent decrease in colony forming units was calculated in different formulations for every 15 days to know the difference in shelf-life of each formulation by using the formula (Smith, 1958):

Per cent decrease

$=($ Original number - old number $) \times 100$

Original number

\section{Effect of different formulations of Trichoderma on root rot (Rhizoctonia sp.)}

Trichoderma formulations based on agricultural waste materials were used as seed treatments. For seed treatment, seeds were soaked in water one day before sowing and were then smeared with Trichoderma formulations uniformly by hand under shade.

A green house experiment was conducted to assess the effect of different formulations of Trichoderma sp. prepared on agrowastes on root rot (Rhizoctonia sp.) disease of chilli, cucumber and radish. Only the germination percentage was observed to check the efficacy of Trichoderma formulations. Soil(250 g) was filled in the aluminum-foil containers with drainage hole at the bottom. For preparation of inoculum in the form of infested soil, the pathogen was multiplied on Farm Yard Manure (10g in each container) and was mixed with the soil (Chandar et al., 2016). Treatments used are presented in table 1. The absolute control without seed treatment, soil inoculation was also maintained.

\section{Results and Discussion}

The present investigation was undertaken to evaluate the sporulation and growth of Trichoderma sp. on different agricultural wastes. The growth and sporulation of Trichoderma sp. on different substrates is presented in table 2 .

Sporulation of Trichoderma sp. was observed on cowdung after three days of inoculation, whereas other treatments like rice husk, rice chaffy grains, wheat straw and sawdust in combination with cowdung and waste peels of vegetables like potato, carrot and bottleguard didn't show any growth of Trichoderma sp.The probable reason for such findings may be the concentration of carbon and nitrogen that had the effect on sporulation of $T$. viride in which a lower carbon concentration was beneficial for its sporulation(Gao et al., 2007). Similar findings were reported by Rajput et al., (2015). Waste peels of some fruits like papaya, pineapple and pomegranate showed growth of Trichoderma sp. Complete colonization of Trichoderma was observed after three days in case of pineapple peel and papaya peel, whereas slow growth was seen on banana peel. Growth of Trichoderma sp.on pineapple peel was found to be fast and abundant $\left(2.7 \times 10^{8} \mathrm{cfu} / \mathrm{g}\right)$ andretained good colonies till the end of one week.

The probable reason for such findings may be carbon source and protein content $(35.5 \mathrm{mg})$ that induced the highest enzymatic activity, in turn leading to the faster and abundant growth of Trichoderma sp. (Fortkamp and Knob, 2014). 
Table.1Evaluation of fruit peel formulation of Trichoderma sp. against root rot (Rhizoctonia sp.) of chilli, cucumber and radish

\begin{tabular}{|l|l|l|}
\hline S.No. & Treatment & Treatment Detail \\
\hline $\mathbf{1}$ & $\mathrm{T}_{0}$ & Control+Rhizoctonia $\mathrm{sp}$. \\
\hline $\mathbf{2}$ & $\mathrm{T}_{1}$ & Talc based formulation+ Rhizoctonia $\mathrm{sp}$. \\
\hline $\mathbf{3}$ & $\mathrm{T}_{2}$ & Pineapple peel formulation+ Rhizoctonia $\mathrm{sp}$. \\
\hline $\mathbf{4}$ & $\mathrm{T}_{3}$ & Carbendazim+ Rhizoctonia $\mathrm{sp}$. \\
\hline
\end{tabular}

Table.2 Growth and sporulation of Trichodermasp. on different substrates

\begin{tabular}{|c|c|c|c|}
\hline S. No. & Treatments & Treatment Detail & $\begin{array}{l}\text { Growth and sporulation of } \\
\text { Trichoderma sp. }\end{array}$ \\
\hline 1 & $\mathrm{~T}_{1}$ & Cowdung & Medium and slow \\
\hline 2 & $\mathrm{~T}_{2}$ & Cowdung + rice husk & No growth \\
\hline 3 & $\mathrm{~T}_{3}$ & Cowdung + wheat straw & No growth \\
\hline 4 & $\mathrm{~T}_{4}$ & Cowdung + rice chaffy grains & No growth \\
\hline 5 & $\mathrm{~T}_{5}$ & Cowdung + sawdust & No growth \\
\hline 6 & $\mathrm{~T}_{6}$ & Papaya peel & Fast and moderate \\
\hline 7 & $\mathrm{~T}_{7}$ & Pineapple peel & Fast and abundant \\
\hline 8 & $\mathrm{~T}_{8}$ & Pomegranate peel & Medium and slow \\
\hline 9 & $\mathrm{~T}_{9}$ & Potato peel & No growth \\
\hline 10 & $\mathrm{~T}_{10}$ & Carrot peel & No growth \\
\hline 11 & $\mathrm{~T}_{11}$ & Bottle gourd peel & No growth \\
\hline
\end{tabular}

Table.3 Shelf-life evaluation of fruit peel formulation of Trichoderma sp.

\begin{tabular}{|c|l|l|l|l|l|l|}
\hline $\begin{array}{c}\text { Treatment } \\
\text { Numbers }\end{array}$ & Treatments & 0 Days & 15 Days & 30 Days & 45 Days & Mean \\
\hline $\mathbf{T}_{\mathbf{0}}$ & $\begin{array}{l}\text { Talc } \\
\text { formulation }\end{array}$ & 2.10 & 2.00 & 1.80 & 1.50 & 1.85 \\
\hline $\mathbf{T}_{\mathbf{1}}$ & $\begin{array}{l}\text { Pineapple peel } \\
\text { formulation }\end{array}$ & 3.10 & 3.00 & 2.80 & 2.60 & 2.88 \\
\hline $\begin{array}{l}\text { Overall } \\
\text { Mean }\end{array}$ & $\mathbf{2 . 6 0}$ & $\mathbf{2 . 5 0}$ & $\mathbf{2 . 3 0}$ & $\mathbf{2 . 0 5}$ & \\
\hline
\end{tabular}


Table.4 Efficacy of fruit peel formulation of Trichoderma sp. against root rot (Rhizoctonia sp.) of vegetable crops

\begin{tabular}{|l|l|l|l|l|}
\hline $\begin{array}{l}\text { Treatment } \\
\text { Numbers }\end{array}$ & Treatments & \multicolumn{3}{|l|}{ Germination (\%) } \\
\hline & & Chilli & Cucumber & Radish \\
\hline $\mathbf{T}_{\mathbf{0}}$ & Control & 39.57 & 69.43 & 75.68 \\
\hline $\mathbf{T}_{\mathbf{1}}$ & Talc based formulation & 66.65 & 84.70 & 89.56 \\
\hline $\mathbf{T}_{\mathbf{2}}$ & Pineapple peel formulation & 74.98 & 92.34 & 96.50 \\
\hline $\mathbf{T}_{\mathbf{3}}$ & Carbendazim formulation & 57.62 & 79.15 & 86.09 \\
\hline
\end{tabular}

Present findings were similar to the results reported by Simon and Anamika (2011), Nagarbabu and Pallavi (2013), Sangle and Bambawale (2005), Sharma et al., (2005).

\section{Shelf-life evaluation of Trichoderma sp.}

Only the Pineapple peel was selected as substrate for determining shelf-life of Trichoderma sp.as this substrate showed fast growth and abundant sporulation and was able to retain its colonies till the end of one week.Shelf-life evaluation of fruit peel formulation of Trichoderma sp. is presented in table 3. Maximum shelf-life was recorded in pineapple peel formulation $\left(2.6 \times 10^{8} \mathrm{cfu} / \mathrm{g}\right)$ when compared to talc based formulation $\left(1.5 \times 10^{8} \mathrm{cfu} / \mathrm{g}\right)$.

The percent reduction in colony forming units from 0 to 15 days, 16 to 30 days and 31 to 45 days in talc based formulation and orange peel formulation were $4.7 \%$ and $3.2 \% ; 10 \%$ and $6.67 \% ; 16.67 \%$ and $7.14 \%$, respectively. Thus, it shows that orange peel formulation provides healthier conditions for the stay of viable spores for longer duration than that of the talc based formulation. The probable reasons for such findings may be the chemical composition and nutritional status of the substrate that might have increased the shelflife of Trichoderma sp. Similar findings were reported by Gaur et al., (2005) and Das et al., (2006).

\section{Efficacy of fruit peel formulation of Trichoderma sp.}

Against root rot (Rhizoctonia sp.) of of chilli, cucumber and radish

After 10 days of sowing of vegetable crops, maximum germination percentage was recorded in $\mathrm{T}_{2}$ - Pineapple peel formulation of Trichoderma sp. followed by $\mathrm{T}_{1}$ - Talc based formulation, $\mathrm{T}_{3}$ - Carbendazim and $\mathrm{T}_{0}$ Control (untreated check) as presented in table 4. The Pineapple peel formulation of Trichodermasp.,a fruit waste formulation was found to be the most effective against root rot caused by Rhizoctonia sp. in all the vegetable crops.

The probable reason for present findings may be that volatile antibiotics and secondary metabolites produced by Trichoderma sp.are inhibitory to Rhizoctonia solani (Dennis and Webster, 1971).The antibiosis, mycoparasitic, 
symbiont opportunistic and nutrition competative nature of Trichoderma sp. might also have been the reason. Similar findings have also been reported by Anand and Reddy (2009); Ambuse et al., (2012).

\section{References}

Ambuse, M. G., Chatage, V. S. and Bhale, U. N. (2012). Influence of Trichoderma spp. against Alternaria tenuissima inciting leaf spot of Rumex acetosa $L$. Bioscience Discovery, 3(2):259-262.

Anand, S. and Reddy, J. (2009). Biocontrol potential of Trichoderma sp. against plant pathogens. International Journal of Agricultural Science, 2:30-39.

Chandar, K., Gangopadhyay, S. and Godara, S. L. (2016). Eco-friendly management of wilt caused by Fusarium oxysporum f.sp. ciceri in chickpea. Legume Research - An International Journal, 39(1):129-134.

Das B. C., Das, B. K., Dutta, P. B. and Sarmah, D. K. (2006). Bioformulation of $T$. harzianum for management of soybean stem rot caused by $R$. solani. Journalof Biological Control, 2 (1):5764.

Fortkamp, D. and Knob, A. (2014).High xylanase production by Trichoderma viride using pineapple peel as substrate and its application in pulp biobleaching. African Journal of Biotechnology, 13(22):2248-2259

Gao Li, Man H. Sun, Xing Z. Liu and Yong S. Che (2007).Effects of carbon concentration and carbon to nitrogen ratio on the growth and sporulation of several biocontrol fungi. Mycological Research, 111:87-92.

Gaur, R. B., Sharma, R. N. and Sharma, R. R. (2005). Shelf life of talc based Formulation of Trichoderma and Soil Application for Biological Control of Dry Root-Rot of Chickpea. Journal of
Mycology and Plant Pathoogy, 35(2) : 380-384.

Kamala, T. and S. Indira Devi, (2012). Biocontrol properties of indigenous Trichoderma isolates from North-east India against Fusarium oxysporum and Rhizoctonia solani. African Journals of Biotechnology, 1(34): 8491-8499.

Nagur Babu, K. and Pallavi, P. N. (2013). Isolation, identification and mass multiplication of Trichoderma an important bio-control agent. International Journal of Pharmacy \& Life Sciences, 4(1): 2320-2323.

Rajput, A. Q., Khanzada, M. A., and Shahzad, S. (2014). Effect of Different Organic Substrates and Carbon and Nitrogen Sources on Growth and Shelf Life of Trichoderma harzianum.Jornal of Agricultural Sciences and Technology, 16: 731-745.

Rajput, A. Q. and Saleem shahzad (2015). Growth and sporulation of Trichoderma polysporum on organic substrates by addition of carbon and nitrogen sources. Pakistan Journal of Botany, 47(3): 979-986.

Sangle, U. R. and Bambawale, O. M. (2005).Evaluation of substrates for mass multiplication of Trichoderma spp. Indian Journal of Plant Protection, 33: 298-300.

Sanjay, S. S. (2010).Development of improved technology for mass multiplication of Trichoderma spp., a biofungicide. Thesis submitted to Indira Gandhi Krishi Vishwavidyalaya, Raipur.

Schmidt, E. L. and Caldwell, A.C. (1967). A practical manual of soil Microbiology Laboratory Methods. Food and Agric. Organization of the United Natons Soil Bull., pp.72-75.

Sharma, S., Agarwal, A., Prakash, V. and Sharma, D. (2005). Mass production of VAM fungi using different substrates 
and hosts. Journal of Mycopathological Resources, 43: $51-56$.

Simon, S., and Anamika (2011). Agro-based Waste Products as a Substrate for Mass Production of Trichoderma spp.
Journal of Agricultural Science, 3(4):168-171.

Smith, D. E. (1958).History of Mathematics, Courier dover publications, pp: $247-$ 249.

\section{How to cite this article:}

Suma, Y. M., T. Anil Kumar, S. Simon and Lal, A. A. 2019. Shelf-life Evaluation of trichoderma sp. on Agricultural Waste Materials. Int.J.Curr.Microbiol.App.Sci. 8(09): 19031909. doi: https://doi.org/10.20546/ijcmas.2019.809.220 